\title{
Coping Strategies of Diabetic Yam Farming Households in Benue State, Nigeria
}

\author{
Teran, A. $\mathrm{D}^{1}$, Tsue, P. $\mathrm{T}^{2}$ \\ ${ }^{1}$ Department of Agricultural Economics, University of Nigeria, Nsukka \\ ${ }^{2}$ Department of Agricultural Economics, University of Agriculture, Makurdi, Nigeria.
}

\begin{abstract}
This study engaged the Multinomial Logistic Model (MLN) to determine factors influencing te choice of coping strategies of diabetic yam farming households in Benue State, Nigeria. A multi-stage random sampling technique was used to select 340 yam farming households with emphasis on 2015 farming season. Primary data were obtained using a well structured and pretested questionnaire. The results of analysis shows that the most frequently used coping strategies were special diets such as millet, cocoyam, locust bean, groundnut, fruits and vegetables accounting for 39\%, constant intake of drugs like metformin, biguarnide, sulphorylureas and insulin $25 \%$, hired labour, $23.2 \%$, routine exercise, $12.6 \%$, while hawking was $0.3 \%$. The choice of constant drug was -0.012, while the choice of hawking was significantly $(p<0.05)$ and negatively affected by education as a coping strategy. The marginal effect of education on constant drug was 0.012 , while the choice of hawking was significantly ( $p<$ 0.05 ) and positively affected by the age as a coping strategy. The marginal effect of age on hawking was 0.04. It is recommended that government at Federal, State and Local levels with partners in progress should consider critical ways of managing diabetes by emphasizing healthy lifestyles such as ceasation of smoking, moderate alcohol intake, regular medical check-up and improvement of the socio-economic status of the diabetic farm households through good road network, steady supply of electricity which will better the quality of life of the farm households.
\end{abstract}

Keywords-Yam Farming, FO, IDF.

\section{INTRODUCTION}

Available records from International Diabetic Federation (IDF), 2010) indicates that access to appropriate diabetes cure in Sub-Saharan Africa is extremely limited because of inadequate health care system, shortage of doctors, unaffordability of medication and other equipment. The poor, especially farmers, resort to traditional source or resign to fate, leading to improper management. Therefore, farmers who are victims or caregivers face farm labour supply shortage. This had impair food crop production. The study focused on the effects of diabetic scourge on yam crop farmers in Benue State. The choice of yam for the study was because yam is the predominant crop cultivated by farmers in the State.

According to Giwa and Tayo (2013), socio-economic characteristics such as family size, educational level, marital status, age, gender, and income level influence the ability of individual to cope with diabetes illness. This involves knowledge, self-care skills, household labour hiring, practice aimed at cushioning the effect of diabetes on income, increased efforts made by families members at the time of illness and death (Motala, 2013).

Diabetes represents a large financial cost to the society and individuals. The process of seeking treatment involves cost and expenditures on drugs and medication, transport, funeral rites of individual and families. The fear of contracting diabetes also urges people to protect themselves. The theory of averting behaviors predicts that a person will continue to take protective measure as long as the perceived benefits exceed the cost of doing so. The government also ensures that resources are provided to maintain and operate a good health system to enhance efficient and effective productivity.

Spencer (2002) showed that farmers must be assisted to increase production through more efficient use of resources. The full potential of land, capital and labour resources are yet to be fully tapped into due to poor health of farmers and related factors (Aboderin, 2010). Diabetes, therefore, is not only a public health problem but also a developmental problem. At the national level, apart from the negative effects of low productivity on the major sectors of the economy, diabetes had negative effects on saving, trade and investment potentials (Strauss \& Thomas, 1998).Some affected farm households and caregivers resort to soliciting claims from support network and untimely sale of farm produce, belongings, livestock, food reserves, capital assets, borrowing from money lenders and reduction in nutritional value of their food consumption. This could effects 
agricultural productivity, therefore the study examined the coping strategies of farm households.

\section{METHODOLOGY}

The study area was Benue State, Nigeria. "The Food Basket of the Nation", was created in 1976 with its name derived from River Benue, the second largest river in Nigeria. The administrative headquarters is Makurdi and it is composed of 23 Local Government Areas and 423 Council Wards. The State is located in the North Central region of Nigeria, which is the transition zone from the Northern and Southern ecologies. It lies between longitude $6^{0} 31^{\prime} \mathrm{E}$ and $10^{\circ} \mathrm{E}$ and Latitudes $6^{0} 30^{\prime} \mathrm{N}$ and $8^{0} 10^{\prime} \mathrm{N}$ (BNARDA, 2005). The State shares boundaries with five neighbouring states: Nassarawa to the North; Taraba to the East; Cross River and Enugu to the South-East; Enugu and Kogi to the West. The eastern part of the state is also bounded with the Republic of Cameroun.

Benue State has a total land mass of about 33, $955 \mathrm{~km}^{2}$ (BNARDA, 2005). Agriculturally the State is divided into three zones:Zone A (Katsina-Ala, Ukum, Ushongo, Vandeikya, Logo, Kwande and Konsisha, LGAs); Zone B (Gboko, Tarka, Buruku, Gwer-east, Gwer-West, Guma and Makurdi, LGAs); and Zone C (Ado, Agatu, Apa, Otukpo, Ohimini, Okpokwu, Ogbadigbo, Obi and Oju, LGAs). The state has a total population of 4, 219, 244 people and 413, 159 households (National Population Commission (NPC), 2006; BNARDA, 2005).

The state has favourable agro-climatic ecologies for arable crops, tree crops and livestock production and enjoys two distinct seasons; rainy season, beginning from April to October, and dry season, from November, to March. Annual rainfall records vary from $1700 \mathrm{~mm}$ in the southern part to $1250 \mathrm{~mm}$ in the northern ecology of the state with annual temperature variations of $30^{\circ} \mathrm{C}$ and $35^{\circ} \mathrm{C}$ (Benue State Government (BNSG), 2011). The three major ethnic groups are the Tiv, Idoma and Igede. Other smaller ethnic group are Etulo, Abakpa, Akwaya and Jukun. Yam is the major crop produced in the State; and it is consumed in a variety of forms with sauce and soup, including pounded yam, roasted, fried and porridge (BNARDA, 2004). Yam is used as delicacy during marriage, birthday, funeral and other social and religious ceremonies in large quantities. Benue State, the Food Basket of the Nation with $70 \%$ of its population depending on agriculture as their main source of livelihood (BNARDA, 2004) ranked very high among the diabetic endemic States in Nigeria (DAN, 2014).

\section{DATA AND ANALYTICAL TECHNIQUE}

Data for this study were collected from primary sources. The primary data were collected from the diabetic yam farming households using a well structured and pretested questionnaire. The questionnaire was administered with the assistance of extension agents from Benue State Agricultural and Rural Development Agency and Diabetes Association of Nigeria, Benue State chapter with emphasis on 2015 farming season. The data collection instrument focused on prevalence and incidence of diabetes, socioeconomic characteristics of households, direct and indirect cost in form of registration fees, consultation fees, laboratory test, transportation, productivity lost by diabetic patients, caregivers and substitute labour. The questionnaire also capture information on dietary habits, lifestyle, technical efficiency as well as factors influencing choice and coping strategies of the households. The instrument was administered to the household head.

The multinomial logistic regression model was used to determine household's socio-economic and demographic factors that influenced choice of coping strategies. The multinomial logistic regression was expressed as adopted by Sofoluwe, Tijani and Baruwa(2011) as:

$P_{i j}=\frac{\exp \left(\beta_{j} X_{i}\right)}{1+\sum_{j=1}^{5} \exp \left(\beta_{j} X_{i}\right)}$ forj $=1,2,3,4,5 \ldots \ldots \ldots \ldots$

$\mathrm{P}_{\mathrm{ij}}$ is the probability of being in each of the groups $2,3,4$ and 5 .

$P_{i 0}=\frac{1}{1+\sum_{j=1}^{5} \exp \left(\beta_{j} X_{i}\right)}$ for $j=1$

$\mathrm{P}_{\mathrm{i} 0}$ is the probability of being in the reference group 1 .

In practice, when estimating the model the coefficients of the reference group are normalized to zero (Maddala, 1990; Greene, 1993; Kimhi, 1994). This is because the probabilities for all the choices must sum up to unity (Greene, 1993). Hence, for 5 choices only (5-1) distinct sets of parameters can be identified and estimated.

The natural logarithms of the odd ratio of equations (1) and (2) give the estimating equation (Greene, 1993) as:

$\ln \frac{\left[P_{i j}\right]}{\left[P_{i 0}\right]}=\beta_{j} X_{i}$

This denoted the relative probability of each of group 2,3,4 and 5 to the probability of the reference group $(j=1)$. The estimated coefficients for each choice, therefore, reflected the effects of Xi's on the likelihood of the farm household choosing that coping strategy relative to the reference group. However, following Hill (1983), the coefficients of the reference group might be recovered by using the formula:

$$
\beta_{1}=-\left(\beta_{2}+\beta_{3}+\beta_{4}+\beta_{5}\right) .
$$


For each explanatory variable, the negative of the sum of its parameters for groups 2,3,4 and 5 is the parameter for the reference group.

$\mathrm{Xi}$ are socio-economic and demographic variables which influence decision to choose a coping strategy. They were:

MS = Marital status of household head $($ married $=1$, otherwise $=0$ );

$\mathrm{SH}=\mathrm{Sex}$ of household head (male $=1$, female $=0)$;

$\mathrm{AH}=$ Age of household head (years);

$\mathrm{LE}=$ Years of educational attainment of household head;

$\mathrm{HS}=$ Household size (number);

FS = Farming experience of the household head (years);

FI = Farm income of the household head ( $)$;

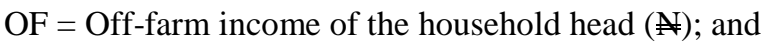

$\mathrm{RM}=$ Remittance to the household head ( $)$.

\section{RESULTS AND DISCUSSION}

Table 1 shows the percentage of households adopting particular strategy to cope with diabetic scourge in the study area. The most frequently used coping strategy by affected households was consumption of special diets such as millet, cocoyam, locust bean, groundnut fruits and vegetables making up to $38.8 \%$. Weil (2004) found that special diets enhanced one's ability to cope with diabetes and stress. The high ranking of diet among other coping mechanisms might be related to the numerous advertisements on media on what to eat to reduce the incidence of diabetes mellitus by naturalistic, traditional healers and herbalist. About $25.0 \%$ embarked on constant intake of drugs such as biguarnides, insulin, sulphornylureas, statins and antihypentisives. Some authorities such as Enwere, Salako and Falade (2006), who investigated the prescription and cost consideration at a diabetic clinic in Ibadan, Nigeria, recommended constant drug intake as a prerequisite for coping with diabetes despite their high cost.

About $23.2 \%$ of respondents employed hired labour to cope with diabetes. This is necessary because diabetes scourge has significant adverse effects on household composition, labour supply, cropping pattern and food production. In assessing the effectiveness of households coping strategies with diabetes and heart-related ailments in Nigeria, DAN (2014) reported that hired labour played a central and crucial role while manual labour supply remained a major source of production.

The result further showed that $12.6 \%$ of respondents embarked on routine exercise to cope with diabetes illness while $0.3 \%$ survived by hawking. These findings are at variance with Jiang and Braun (2005) who reported households coping strategies with ill-health risk to include, selling of productive assets such as farm equipment, land, breeding animals, hired labour, borrowing from friends, withdrawing of children from schools, hawking, exercising, community based support. Variation in coping between households could be based on differences in asset base, age of household head, educational level as well as gender.

Table.1: Major Coping Strategies of Diabetic Farming Households ( $n=340)$

\begin{tabular}{lll}
\hline Strategies & Frequency & Percentage $\mathbf{( \% )}$ \\
\hline Special diet & 132 & 38.8 \\
Regular exercise & 43 & 12.6 \\
Constant drugs & 85 & 25.0 \\
Hired labour & 79 & 23.2 \\
Hawking & 1 & 0.3 \\
\hline
\end{tabular}

\section{Source: Field survey data, 2015.}

The result of multinomial logit analysis showed the factors that influenced the choice of coping strategies by the respondents (table 2). The coefficients for each choice (special diets, constant drugs, hawking, hired labour) reflect the effects of socioeconomic and demographic variables such as age, sex, marital status, education, household size, farming experience, farm income, non-farm income and remittance on choice of a particular coping strategy. The significance of likelihood ratio chi-square (118.21) at $1 \%$ level implied that, the regression had a good fit. The result showed that the set of significant explanatory variables across the reference base group in terms of the level of significance and signs of the parameter estimate for factors influencing choice of coping strategies.

Age of the household head (0.09) positively and significantly influenced the choice of hawking as opposed to constant exercise as a coping strategy at $5 \%$. As age of household head increased, the more likely they are going to send their children for hawking in order to raise money rather than embark on exercise. The marginal effect of age 
on hawking, as shown in table 3, was 0.004. This implied that a unit increase in the age of household head would increase hawking activities by $0.004 \%$. Wu and Porell (2000) stated that most aged diabetes patients might even be too weak and with other complications to embark on constant exercise as a coping strategy.

The sex of the household head (-1.73) negatively and significantly influenced the choice of hawking as a coping strategy of diabetic farm households at $1 \%$ level.

Table.2: Parameter Estimates of Multinomial Logistic Regression Model for coefficient Factors Influencing Choice of Coping Strategies

\begin{tabular}{lllll}
\hline Variables & Special diet & Constant drugs & Hawking & Hired labour \\
\hline Age & 0.04 & 0.04 & 0.09 & -0.01 \\
& $(1.04)$ & $(1.34)$ & $(1.95)^{* *}$ & $(-0.43)$ \\
Sex (male=1,female=0) & -0.60 & -0.39 & -1.73 & -0.42 \\
& $(-1.09)$ & $-0.78)$ & $(-3.06)^{*}$ & $(-1.12)$ \\
Marital status & 0.94 & 1.47 & 2.00 & 0.35 \\
(married=1, & $(1.09)$ & $(1.99)^{* *}$ & $(2.28)^{* *}$ & $(0.74)$ \\
otherwise=0) & & & & \\
Education & 0.08 & -0.08 & -0.64 & 0.35 \\
& $(1.76)$ & $(-2.12)^{* *}$ & $(-0.36)$ & $(0.74)$ \\
Household size & -0.11 & -0.05 & -0.06 & -0.01 \\
& $(-1.53)$ & $(-0.97)$ & $(-0.88)$ & $(-0.45)$ \\
Farming experience & 0.001 & -0.02 & -0.08 & 0.35 \\
& $(0.03)$ & $(-0.88)$ & $(-2.46)^{* *}$ & $(1.72)$ \\
Farm income & $-4.29 \mathrm{E}-6$ & $1.18 \mathrm{E}-06$ & $-2.40 \mathrm{E}-06$ & $-3.14 \mathrm{E}-06$ \\
& $(-3.49)^{*}$ & $(-1.76)$ & $(-1.78)$ & $(-4.15)^{*}$ \\
Non-farm income & $-9.54 \mathrm{E}-6$ & $-4.55 \mathrm{E}-06$ & $-2.36 \mathrm{E}-06$ & $-1.74 \mathrm{E}-08$ \\
& $(-2.37)^{* *}$ & $(-1.76)$ & $(-1.17)$ & $(-0.01)$ \\
Remittance & $-1.1 \mathrm{E}-4$ & $-1.20 \mathrm{E}-06$ & $5.15 \mathrm{E}-06$ & $-0.000^{*}$ \\
Constant & $(-1.10)$ & $(-0.23)$ & $(1.14)$ & $(-2.45)$ \\
& -2.03 & -2.95 & -3.57 & 0.14 \\
Number of observation & $(-1.000)$ & $(-1.87)$ & $(-1.53)$ & $(0.12)$ \\
LR chi-square & 340 & & & \\
Prob > chi square & $(36) .118 .21^{*}$ & & & \\
Pseudo R & 0.000 & & & \\
\hline
\end{tabular}

Reference category $=$ constant exercise

*,** significant at $1 \%$ and $5 \%$ level.

Numbers in parenthesis are z-values

Source: Field data analysis, 2015.

Table.3: Marginal Effects of Coefficients Influencing the Choice of Coping Strategies of Diabetic Farming Households.

\begin{tabular}{lclll}
\hline Variables & & \multicolumn{2}{c}{$\boldsymbol{d y}$} \\
& Special diet & Constant drugs & Hawking & Hired labour \\
\hline Age & 0.002 & 0.0043 & 0.0042 & -0.0062 \\
& $(0.90)$ & $(1.26)$ & $(1.92)$ & $(-1.21)$ \\
Sex (male=1, female=0) & -0.017 & -0.0045 & -0.1080 & -0.0205 \\
& $(-0.49)$ & $(-0.09)$ & $(-2.13) * *$ & $(-0.30)$
\end{tabular}




$\begin{array}{lllll}\begin{array}{l}\text { Marital status } \\ \text { (married=1,otherwise=0) }\end{array} & 0.032 & 0.094 & 0.049 & 0.0029 \\ & (0.92) & (2.51)^{*} & (2.90)^{*} & (0.03) \\ \text { Education } & 0.0051 & -0.012 & -0.0024 & 0.0143 \\ & (1.76) & (-2.92)^{*} & (-0.89) & (2.46)^{* *} \\ \text { Household size } & -0.0061 & -0.0038 & -0.0019 & 0.0015 \\ & (-1.39) & (0.67) & (-0.61) & (0.23) \\ \text { Farming experience } & -0.0001 & -0.0033 & -0.0044 & 0.0092 \\ & (-0106) & (-1.19) & (-2.92)^{*} & (2.39)^{* *} \\ \text { Farm income } & -2.09 \mathrm{E}-07 & 2.92 \mathrm{E}-07 & -6.31 \mathrm{E}-08 & -5.68 \mathrm{E}-07 \\ & (-2.81)^{*} & (3.70)^{*} & (-0.99) & (-4.00)^{*} \\ \text { Non-farm income } & -5.47 \mathrm{E}-07 & -4.02 \mathrm{E}-07 & -5.30 \mathrm{E}-08 & 3.77 \mathrm{E}-07 \\ & (-2.52)^{*} & (-1.50) & (-0.55) & (1.43) \\ \text { Remittance } & -4.13 \mathrm{E}-07 & 4.55 \mathrm{E}-07 & 5.12 \mathrm{E}-07 & -2.84 \mathrm{E}-06 \\ & (-0.68) & (0.78) & (2.08)^{*} & (-2.40)\end{array}$

$(+) d y / d x$ is a discrete change of dummy variable from 0 to 1. *,** significant at $1 \%$ and $5 \%$ level.

Source: Field data analysis, 2015.

An increase in the number of male household heads would inrease the probability of choosing constant exercise as a coping strategy against hawking. The marginal effects of sex on hawking as shown in table 3 was -0.108 . This implied that increase in the number of male headed households by $1 \%$ would reduce hawking as a coping strategy of diabetes by $0.108 \%$. while increases in the number of female headed households by $1 \%$ will increase hawking as a coping strategy of diabetes by $0.108 \%$. This is consistent with the findings of Oguntola (2011) who reported that men coped better with diabetes by embarking on routine exercise and other coping measures than women. The coefficient of marital status was positively and significantly related with the choice of constant drugs (1.47) and hawking (2.00) as coping strategy of diabetic farm households at 5\%. This is an indication that married household heads would rather embark on intake of constant drugs and hawking as coping strategies than constant exercise while the single household heads, (widow/widower) tended to favour constant exercise. The marginal effects of marital status on constant drugs and hawking as shown in table 3 was 0.094 and 0.049 respectively. This implied that a $1 \%$ increase in marriage among household heads would lead to an increase in constant intake of drugs and hawking by $0.094 \%$ and $0.049 \%$, respectively.

This could be due to inflexible work schedule; unmet need for child care and lack play ground, park and public gym for constant exercise. Community may also be crime ridden and there may be no nearby indoor places for exercises.
Basically, efforts to keep household members safe and indoor may encourage sedentary behaviour such as watching Nigerian movies and playing video games which are risk factors of diabetes. Single household heads may find it easier to hawk without cautions, support extracurricular activities and constant exercise as a coping strategy compared to married households head.

Similarly, the coefficient of education (-0.08) was negative and statistically significant on constant drugs at $5 \%$. This implied that increase in the level of education of household head would increases the probability of choosing constant exercise against constant intake of drugs as coping strategy. The marginal effect of education on constant drugs was (0.012 ) as shown in table 3 . This means that a unit increase in education of household heads would reduce constant intake of drugs as a coping strategy of diabetes by $0.012 \%$. This could be because educated people are more enlightened and informed on the danger of being constantly on drugs and would prefer to be involved in constant exercise as a coping strategy. The more people learn, the more they become experts in coping with ill- health by embarking on exercises and other physical activities. The role of education in coping with chronic illnesses, like diabetes, had been documented in literature. ADA (1999) reported that diabetic adults with high school education embark more on routine exercise as a coping strategy compared with college graduates. Chinenye et al. (2014) confirmed that the higher level of education increased the quantum of coping with diabetes scourge in Nigeria. The role of education and physical activity as a coping strategy 
in reducing the rates of disease and death from chronic illness has been well established (Ross, 2000).

The coefficient of farming experience (-0.08) was negative and statistically significant on hawking at $5 \%$. This implied that increase in farming experience of household heads would increase the probability of choosing constant exercise as against hawking. The marginal effect of farming experience on hawking as shown in table 3 was, (0.0044).This implied that increase in farming experience of household heads would reduce hawking as a coping strategy by $0.0044 \%$. A well experienced diabetic farm households head would have a good knowledge of the impact of exercise over hawking. This would exert a positive influence on coping strategy of diabetic farm households. Using data on youth and diabetes care, Bundick (2011) found the same pattern among young individuals.

The coefficients of farm income (-4.29E-06) was negative and statistically significant on special diet and hired labour at $1 \%$. This implied that an increase in farm income would increase the probability of choosing constant exercises as against special diet and hired labour. The marginal effects of farm income on special diet and hired labour, as shown in table 3 were $-2.09 \mathrm{E}-7$ and $-5.68 \mathrm{E}-07$. This showed that an increase in farm income of household head would reduce the consumption of special diet and hiring of labour as coping strategies by $2.09 \mathrm{E}-07 \%$ and $5.68-07 \%$. This could be as a result of failed diet and failed hired labour. Also, as the income of diabetes household heads improved they could afford to purchase exercise and indoor equipment which were beyond their means previously. Many diabetes victims live in disadvantaged communities where healthy special diet like vegetables, fruits, groundnut, locust bean are available, but are considered unfashionable for consumption due to ignorance and lack of dietary education (IDF, 2012).

Likewise, the coefficient of non-farm income (-9.54E-6) was negative and statistically significant on special diet at 5\%. This implied that increase in non-farm income of the household head would increase the probability of choosing constant exercise as against special diet such as millet, fruits and vegetables. The marginal effects of non-farm income on special diet as shown in table 3 was $-5.47 \mathrm{E}-07$. Thus increase in non-farm income of household head would reduce special diet as a coping strategy by $5.47 \mathrm{E}-07 \%$. This could be because individual household heads who perceived themselves as capable of acquiring more income other than farming income are more likely to purchase exercise and indoor equipment and so may embark on exercise as a coping strategy, while looking fit and healthy without adding weight. This could also be because exercise as a coping strategy is relatively inexpensive, across gender and associated with reduced progression of diabetes and its complications. Umeadi and Chinenye (2014) concurred that exercise improved sensitivity of the body cells to insulin, improved lipid profile/cholesterol, cardiovascular respiratory health and increased metabolism.

The coefficient of remittance (-1.2E-4) was negative and statistically significant on labour at $1 \%$. This implied that with an increase in remittance, would increase the probability of choosing constant exercise as against hired labour. The marginal effect of remittance on hired labour, as shown in table 3, was -2.84E-06. This suggested that increase in remittance of household head would reduce hiring of labour by $2.48 \mathrm{E}-06$. This is likely the case where households receiving remittances do not see reasons to engage in farming anymore, but exercise as a form of leisure (Jiang et al., 2002). A minimum of 150 minutes of moderate to vigorous intense aerobic exercise each week spread over at least three days in a week is ideal (Rashid $e t$ al., 2006). Aerobic exercises such as walking and cycling had beneficial effects on diabetes and cardiovascular diseases.

\section{CONCLUSION AND RECOMMENDATIONS}

The study concludes that diabetic yam farming households adopt strategies such as embarking on different forms of exercise, consumption of special diets, hiring of labour, constant intake of drugs intake and hawking to cope with their illness. Variation in coping strategies between households could be based on difference in assets, age of households, educational level as well as gender, marital status, household size, farming experience, farm income, non-farm income and remittance. Its recommended that government at Federal, State and Local levels with partners in progress should consider critical ways of managing diabetes by emphasizing healthy lifestyle such as cessation of smoking, moderate alcohol intake, regular medical checkup and improvement of the socio-economic status of the diabetic farm households through good road network, steady supply of electricity which will better the quality of life of the households.

\section{REFERENCES}

[1] Aboderin, I. (2010). Understanding and Advancing the Health of older populations in Sub-Saharan Africa: Policy Perspective and Evidence Needs. Public Health Review, 32,357-76.

[2] American Diabetes Association (1999). Nutrition 
Recommendations and Principles for people with Diabetes. Diabetes Care, 22, 10 -52.

[3] Benue State Agricultural and Rural Development Authority (2004). "Sex, Shame and Poverty". Report of a Rapid Appraisal of Health Needs in Rural Benue, DFID, Abuja, Nigeria.

[4] Benue State Agricultural and Rural Development Authority (2005). Benue State Agricultural and Rural Development Authority, Makurdi, Nigeria. Annual Report prepared by Planning, Monitoring and Evaluation Unit pp. 8-13.

[5] Bundick, M. J. (2011). Diabetes extracurricular activities, Positive Youth Development, and the Meaningfulness of Engagement. The Journal of Positive Psychology, 6, (1), $57-74$.

[6] Chinenye, S., Oko-Jaja, R. I. \& Young, E. E. (2014). Diabetes and other Non-Communicable Diseases in Nigeria. The need for primary care in rural setting. Africa Health, 36, 24 -27.

[7] Enwere, O. O., Salako, B. L. \& Falade, C. O. (2006). Prescription and Cost Consideration at a Diabetic Clinic in Ibadan, Nigeria: Annals of Ibadan Postgraduates Medicine, 4(2), 35 - 39.

[8] Giwa, A. \& Tayo, F. (2013). Poverty, Affordability of Anti-diabetic Drugs and glycemic Control: An Unholy Alliance in Developing Economy. Journal of Pharmaceutical Science Research, 4(9), 113-20.

[9] Greene, W. H. (1993). Econometric Analysis.3 ${ }^{\text {rd }}$ (ed), New York : Macmillan Publishers,.

[10] International Diabetes Federation (2010). Diabetes Atlas, Brussels.

[11] International Diabetes Federation (2012). http://www.idf.org/diabetesatlas.

[12] Jiang, R., Manson, J. E. \& Stampfer, M. J. (2002). Nut and Peanut butter Consumption and Risk of type 2 Diabetes in Women. Diabetes Care, 26, 1008 - 1015.

[13] Jiang, R., Manson, J. E. \& Stampfer, M. J. (2002). Nut and Peanut butter Consumption and Risk of type 2 Diabetes in Women. Diabetes Care, 26, 1008 - 1015.

[14] Kimhi, A. (1994). "Participation of Farm Owners in Farm and off-Farm work including the option of fulltime off farm work" Journal of Agricultural Economics, 45(2), 232-239.

[15] Maddala, G. S. (1990). Introduction to Econometrics. New Jersey: Prentice-Hall Inc.

[16] Motala, A. A. (2013). Diabetes trends in Africa. Diabetes Medicals Research, 18, 514 -20.

[17] National Population Commission (2010). National Population Census, Federal Republic of Nigeria Official
Gazette, 94,3-5. Lagos, Nigeria.

[18] Oguntola, S. (2011). Why men develop diabetes more easily than women. http://www.tribune.com.ng (retrieved $6^{\text {th }}$ September, 2012).

[19] Rashid, D. A., Langworthy, M. \& Aradhyula, S. A. (2006). Livelihood shocks and Coping Strategies. An empirical study of Bangladesh Household. A paper presented at the Agricultural and Applied Economics Association Annual Meeting, Long Beach July, 23 26.

[20] Ross, C. E. (2000). Walking, Exercise and Smoking: Does neighbourhood matters? Social Science Medicine, $41,265-274$.

[21] Sofoluwe, N. A., Tijani, A. A., \& Baruwa, O. I. (2011). Farmers Perception and Adaptation to Climate Change in Osun State, Nigeria. African Journal of Agricultural Research, 6(20) 4786 - 4794.

[22] Spencer, D. (2002). The Future of Agriculture in SubSaharan Africa and South Asia: Sustainable Food Security for all by 2020, Proceedings of an International Conference, September, 4 - 6, Washington D.C. USA.

[23] Strauss, J. \& Thomas, D. (1998). Health, Nutrition and Economic Development. Journal of Economic Literature, 5, 766-817

[24] Umeadi, M. \& Chineye, S. (2014). Dietary Management of Diabetes in Nigeria. Port Harcourt: Johnson Publishers Ltd.

[25] Weil, D. (2001). Accounting for the Health on Economic Growth. Memeo: Brown University Press .

[26] Wu, B. \& Porell, F. (2000). Job Characteristics and leisure physical activity. Journal of Aging Health, 12, 538 - 559. 